\title{
VLE of Carbon Dioxide-Loaded Aqueous Potassium Salt of $L$-Histidine Solutions as a Green Solvent for Carbon Dioxide Capture: Experimental Data and Modelling
}

\author{
Afaf Syalsabila,, ${ }^{1,2}$ Abdulhalim Shah Maulud (iD, ${ }^{2,3}$ Humbul Suleman, ${ }^{3}$ \\ and Nik Abdul Hadi Md Nordin $\mathbb{D D}^{2}$ \\ ${ }^{1} \mathrm{CO}_{2}$ Research Centre, Universiti Teknologi PETRONAS, Bandar Seri Iskandar, 32610 Perak, Malaysia \\ ${ }^{2}$ Department of Chemical Engineering, Universiti Teknologi PETRONAS, Bandar Seri Iskandar, 32610 Perak, Malaysia \\ ${ }^{3}$ Centre for Energy Resources Engineering, Department of Chemical and Biochemical Engineering, \\ Technical University of Denmark, 2800 Kgs. Lyngby, Denmark
}

Correspondence should be addressed to Abdulhalim Shah Maulud; halims@utp.edu.my

Received 12 September 2018; Revised 31 December 2018; Accepted 14 April 2019; Published 13 May 2019

Academic Editor: Doraiswami Ramkrishna

Copyright (C) 2019 Afaf Syalsabila et al. This is an open access article distributed under the Creative Commons Attribution License, which permits unrestricted use, distribution, and reproduction in any medium, provided the original work is properly cited.

In this study, vapour-liquid equilibrium of $\mathrm{CO}_{2}$-loaded aqueous potassium salt of $L$-histidine was studied for a wide range of temperature $(313.15-353.15 \mathrm{~K})$, pressure $(150-4000 \mathrm{kPa})$, and solvent concentrations $(1-2.5 \mathrm{molar})$. The experimental results show that $L$-histidine has an excellent absorptive capacity for carbon dioxide. When compared to conventional solvent (monoethanolamine) and amino acid salt (potassium $L$-lysinate) at similar process conditions, $L$-histidine has superior absorption capacity. Moreover, modified Kent-Eisenberg model was used to correlate the VLE of the studied system with excellent agreement between the model and experimental values. The model exhibited an AARE\% of 7.87\%, which shows that it can satisfactorily predict carbon dioxide solubilities in aqueous potassium salt of $L$-histidine at other process conditions. Being a biological component in origin, almost negligibly volatile, and highly resistant to oxidative degradation, $L$-histidine offers certain operational advantages over other solvents used and has a promising potential for carbon dioxide capture.

\section{Introduction}

The consent of environmental protocols has resulted to the increase of efforts in research toward reducing the carbon dioxide emissions. In this effort, the main step is to separate the carbon dioxide from process flue and fuel streams. There are various techniques which have been applied for this purpose [1]. Of these techniques, removal of carbon dioxide $\left(\mathrm{CO}_{2}\right)$ by chemical absorption technique is regarded a standout amongst the most industrial process, technologically and commercially. The process has been broadly received in power plant industry. This involves a chemical reaction between the $\mathrm{CO}_{2}$ containing industrial gas streams and a solvent which then results to a greener and cleaner gas released to the atmosphere. Aqueous alkanolamines such as monoethanolamine (MEA) are commonly used. However, this class of solvents has a few downsides like limiting the cyclic $\mathrm{CO}_{2}$ loading capacity and causing an implication in regeneration economically. Aside from being corrosive, they also add to formation of toxic degradation products and solvent losses due to evaporation [2]. The fugitive losses in the environment have been shown to be directly associated with occurrences of cancer and other medical complexities, apart from their adverse contribution in destroying marine and atmospheric ecology [3].

In the current years, research on using amino acid saltbased solvents as another alternative has been centred for carbon dioxide separation related technology. Interestingly, these amino acid salts have similar functional group to the conventional alkanolamines. Hence, it is expected that their reactivity toward carbon dioxide is as good as alkanolamines-based solvents. Apart from that, they possess 
high resistance to thermal and oxidative degradation as well as low in volatility for they are naturally ionic compounds, potentially are a greener solvent for capturing carbon dioxide $[4,5]$. Their application shall result in a much cleaner and environmentally friendly process. Few studies on these systems are presently available in the literature. Majority of these already scant works are oriented toward the provision of precursor vapour-liquid equilibrium (VLE) data for studies, pertaining to kinetics and transport property-based investigations. The VLE data form the base for all design and simulation studies, which eventually leads to proper equipment sizing and better selection of operational parameters, resulting in optimal production.

One of the initial works was performed by Muñoz et al. [6] as part of their study on structure/function relationship in various solutions of amino acid salts, namely, proline, serine, taurine, ornithine, and arginine. They examined that the carbon dioxide capacity in these aforementioned solvents at concentration of 1 molar was comparable to the conventional MEA [6]. Recently, the carbon dioxide solubility in aqueous potassium lysinate solutions has been studied at temperature (313.15-353.15 K), concentration $(1-2.5 \mathrm{M})$, and pressure $(150-4040 \mathrm{kPa})$. It was discovered that lysine offered good absorptive capacity for carbon dioxide, and model results developed based on the KentEisenberg model are coherent with experimental findings [7]. A comprehensive literature review of the similar studies was conducted in the field. Table 1 provides exhaustive summary about the recent studies in the discussed field.

However, it was interesting to note that VLE data for carbon dioxide-loaded aqueous potassium histidinate (HisK) are absent. Although there was a reported literature on physical properties and kinetics of $\mathrm{CO}_{2}$ absorption into this HisK solution from the work of Shen et al. [30], the VLE data for the said system are fictional. Hence, in this study, $\mathrm{CO}_{2}$ solubility of aqueous potassium histidinate solution was measured at pressure ranging from 150 to $4000 \mathrm{kPa}$, temperature from 313.15 to $353.15 \mathrm{~K}$, and solvent concentrations of 1 and 2.5 molar. A reliable high-pressure vapour-liquid equilibrium apparatus was used to perform this experimental study.

VLE data on this said system are likely the most essential ancestor data for the development of mathematical models particularly at predicting the $\mathrm{CO}_{2}$ loading values. For this reason, a mathematical model based on the modified Kent and Eisenberg approach is extended to correlate the equilibrium solubility data of the aforementioned system, with satisfactory results. Although there are several models available for the prediction of $\mathrm{CO}_{2}$ equilibrium data, the thermodynamic modeling efforts for the aqueous amino acid salt solutions have been limited to modified Kent-Eisenberg model [31, 32]. Being computationally simple, this model has been preferably and broadly used by previous researchers with good correlation of their experimental data $[7,25,29]$. Usually, all the nonidealities of the process system are combined in a single/dual correction parameter(s) of the model, that is a function of amine concentration, carbon dioxide loadings, and/or pressure [33], yielding a good relationship between the model's results and the experimental data. Hence, a study on the modeling of $\mathrm{CO}_{2}$ solubility using the Kent and Eisenberg approach appears desirable.

\section{Materials and Methods}

The chemicals used throughout the experimentation are tabulated in Table 2. All chemicals were of sufficient purity and used without further purification. Samples were weighed using a mass balance Sartorius BSA224S-CW $(u=0.1 \mathrm{mg})$. Separate aqueous solutions of 1.0 and 2.5 molar of potassium hydroxide and $L$-histidine were prepared in $250 \mathrm{ml}$ volumetric flasks $(u=0.1 \mathrm{ml})$ using deionized water and micropipettes (Duran). Both solutions were then mixed in equal volumes to create 1.0 molar and 2.5 molar aqueous potassium salt of $L$-histidine. The results of the study were reiterated thrice to ensure the repeatability of the results, using freshly prepared sample of aqueous potassium salt of $L$-histidine, each time.

Pressurized reactor system (PRS) was used to measure the carbon dioxide solubility in the solvent and is shown in Figure 1 . The apparatus has two vessels primarily made up of stainless steel and designed as $600 \mathrm{ml}$ and $200 \mathrm{ml}$ for feed cell and solubility cell, respectively. Each vessel is jacketed with electrically operated heaters. The apparatus has been used previously at various instances to reaffirm the carbon dioxide solubility in various alkanolamines with good reliability [7, 34, 35]. The feed vessel and reactor cell are equipped with a temperature (type: Autonics TK-4S) and pressure (type: Keyence GP-100M) gauge each. The digital temperature and pressure gauges extract data from the system and transfer it to computer data acquisition system. The computer uses a USB data link with LAB View software for data storage and utilization.

In a usual run, the solubility cell was filled with $40 \mathrm{ml}$ of freshly prepared solvent. The system was purged with lowpressure nitrogen $(0.1 \mathrm{kPa})$ for two minutes to ensure the removal of air/oxygen present in the solubility cell. While purging, the feed cell was filled initially with a known quantity of carbon dioxide, $n_{\mathrm{IQ}}$. After completion of nitrogen flush, carbon dioxide gas was then transported to the solubility cell and $n_{\mathrm{FQ}}$ is introduced as $\mathrm{CO}_{2}$ number of moles in the feed tank after transferring to the solubility cell. Thus, the number of moles of $\mathrm{CO}_{2}$ being fed to the solubility cell is calculated as follows:

$$
n_{\mathrm{FD}}=n_{\mathrm{IQ}}-n_{\mathrm{FQ}}
$$

In the solubility cell, the pressure of $\mathrm{CO}_{2}$ gas dropped by times as the gas chemically reacts and dissolves in the solvent which then brought to an equilibrium state. The residual number of moles of $\mathrm{CO}_{2}$ or undissolved gas were calculated by the tmPR-LCVM-UNIFAC equation of state/excess Gibbs energy model [36], using partial pressure of carbon dioxide, $P_{\mathrm{RS}}$ at equilibrium, using

$$
P_{\mathrm{RS}}=P_{\mathrm{PT}}-P_{\mathrm{NT}}-P_{\mathrm{WT}}-P_{\mathrm{AA}} \text {, }
$$

where $P_{\mathrm{PT}}$ is denoted as the total pressure in solubility cell at equilibrium whilst $P_{\mathrm{NT}}, P_{\mathrm{WT}}$, and $P_{\mathrm{AA}}$ are the equilibrium partial pressures of nitrogen, water, and amino acid in the solubility cell, respectively. The value of $P_{\mathrm{RS}}$ was then further 
TABLE 1: Sources of experimental data for carbon dioxide solubility in various aqueous amino acid salt solutions.

\begin{tabular}{|c|c|c|c|c|c|}
\hline Amino acid & Counterion & $P(\mathrm{kPa})$ & $T(\mathrm{~K})$ & $C(\mathrm{M})$ & Source \\
\hline \multirow{7}{*}{$L$-lysine } & Potassium & $150-4040$ & $313.15-353.15$ & $1.0-2.5$ & {$[7]$} \\
\hline & Potassium & 10 & $298.15-323.15$ & $2.0-8.0$ & {$[8]$} \\
\hline & Potassium & $0.1-100$ & $298.15-348.15$ & $0.2-3.0$ & {$[9]$} \\
\hline & Potassium & $0-45$ & $298.15-313.15$ & $0.5-2.5$ & [10] \\
\hline & Potassium & $0.21-20.52$ & $323.15-343.15$ & 2.317 & {$[11]$} \\
\hline & Potassium & $0.47-115.26$ & $298.15-353.15$ & $0.50-2.50$ & [12] \\
\hline & Potassium & $0.21-20.81$ & $313.15-343.15$ & $1.08-2.28$ & [13] \\
\hline \multirow{6}{*}{$L$-proline } & Potassium & 10 & $298.15-323.15$ & $2.0-8.0$ & {$[8]$} \\
\hline & Potassium & $0.1-100$ & $298.15-348.15$ & $0.2-3.0$ & {$[9]$} \\
\hline & Potassium & & $298.15-313.15$ & 2.5 & {$[14]$} \\
\hline & Potassium & 70 & $285.15-323.15$ & $0.5-3.0$ & {$[15]$} \\
\hline & Potassium & $2.90-928.60$ & $313.15-353.15$ & $0.50-2.00$ & [16] \\
\hline & Potassium & $5.20-2583.90$ & $293.15-323.15$ & $0.07-0.066$ & [17] \\
\hline \multirow{2}{*}{$L$-alanine } & 3-(methylamino)propylamine & 10 & $313.15-353.15$ & 2.5 & [18] \\
\hline & Potassium & $0.20-1041.70$ & $313.15-353.15$ & 1.50 & [19] \\
\hline \multirow{2}{*}{$L$-taurine } & Potassium & $1-1000$ & $313.15-353.15$ & $2.0-6.0$ & {$[20]$} \\
\hline & Potassium & 10 & $298.15-323.15$ & $2.0-8.0$ & {$[8]$} \\
\hline \multirow{7}{*}{$L$-glycine } & Sodium & $100-2500$ & $298.15-313.15$ & $1.0-3.0$ & {$[21]$} \\
\hline & Sodium & $0.1-200$ & $303.15-323.15$ & $1.0-3.0$ & [22] \\
\hline & Potassium & $0.1-60$ & $293.15-351.15$ & $0.1-3.0$ & {$[23]$} \\
\hline & Sodium & $0.10-213.50$ & $303.15-323.15$ & $1.0-3.5$ & [22] \\
\hline & Sodium & $92.00-2505.00$ & 313.15 & 1.0 & {$[24]$} \\
\hline & Sodium & $0.59-773.50$ & $313.15-333.15$ & $0.5-2.8$ & [25] \\
\hline & Potassium & $5.10-2508.70$ & $293.15-323.15$ & $0.1-0.9$ & {$[26]$} \\
\hline$L$-threonine & Potassium & $0.10-42.00$ & 313.15 & 1.00 & [23] \\
\hline$L$-aspraginate & Potassium & $7.20-951.20$ & $313.15-353.15$ & $0.5-2.0$ & {$[27]$} \\
\hline$L$-glutamate & Potassium & $5.10-871.40$ & $313.15-353.15$ & $0.5-2.0$ & {$[27]$} \\
\hline$L$-amino-butyric acid & Potassium & $4.60-977.60$ & $313.15-353.15$ & $0.5-2.0$ & [28] \\
\hline$L$-sarcosine & Potassium & $0.20-938.40$ & $313.15-353.15$ & 4.0 & [19] \\
\hline$L$-phenyl alanine & Sodium & $1.35-23.11$ & $303.15-333.15$ & $0.5-1.3$ & [29] \\
\hline
\end{tabular}

TABLE 2: List of materials used.

\begin{tabular}{lcccccc}
\hline Materials & Abbreviation & CAS & Purity & MW (g/mol) & Source & Purification method \\
\hline Histidine & His & $71-00-1$ & 0.995 (mass fraction) & 155.15 & Merck Malaysia (Pvt.) Ltd. & None \\
Potassium hydroxide & $\mathrm{KOH}$ & $1310-58-3$ & 0.850 (mass fraction) & 56.11 & Merck Malaysia (Pvt.) Ltd & None \\
Carbon dioxide & $\mathrm{CO}_{2}$ & $124-38-9$ & 0.999 (mass fraction) & 44.01 & Gas Walker (Pvt.) Ltd & None \\
Nitrogen & $\mathrm{N}_{2}$ & $7727-37-$ & 0.999 (mass fraction) & 28.01 & Gas Walker (Pvt.) Ltd & None \\
\hline
\end{tabular}

used to determine the value of $n_{\mathrm{RS}}$. This $n_{\mathrm{RS}}$ is important for determination of $\mathrm{CO}_{2}$ number of moles absorbed in the solvent, as demonstrated in the following equation:

$$
n_{\mathrm{AB}}=n_{\mathrm{FD}}-n_{\mathrm{RS}} \text {. }
$$

The number of moles in each case $\left(n_{\mathrm{IQ}}, n_{\mathrm{FQ}}\right.$, and $\left.n_{\mathrm{RS}}\right)$ were determined by translated modified Peng-Robinson equation of state [37] and Span and Wagner EoS [38] for pressures lower and higher than $3000 \mathrm{kPa}$, respectively. Hence, the carbon dioxide loading was determined as follows:

$$
\alpha=\frac{n_{\mathrm{AB}}}{n_{\mathrm{AA}}},
$$

where $n_{\mathrm{AA}}$ is the number of moles of unloaded amino acid initially fed to the solubility cell.

\section{Thermodynamic Framework}

3.1. Modified Kent-Eisenberg Model for Absorption of Carbon Dioxide in Aqueous Potassium Histidinate Solution (HisK). The chemical reaction between carbon dioxide and amino acid salt like histidine is best explained by the zwitterion mechanism which broadly recognized for the development of model for $\mathrm{CO}_{2}$ absorption in the aqueous solutions of alkanolamines and amino acid salts [39]. The equations describing the equilibrium of $\mathrm{CO}_{2}$ with $\mathrm{HisK}$ are as follows [30]:

$$
\mathrm{RR}^{-} \mathrm{NH}_{2}^{+} \stackrel{k_{a}}{\rightleftarrows} \mathrm{RR}^{-} \mathrm{NH}+\mathrm{H}^{+}
$$

$$
\mathrm{RR}^{-} \mathrm{NCOO}^{-}+\mathrm{H}_{2} \mathrm{O} \stackrel{k_{b}}{\rightleftarrows} \mathrm{RR}^{-} \mathrm{NH}+\mathrm{HCO}_{3}^{-}
$$




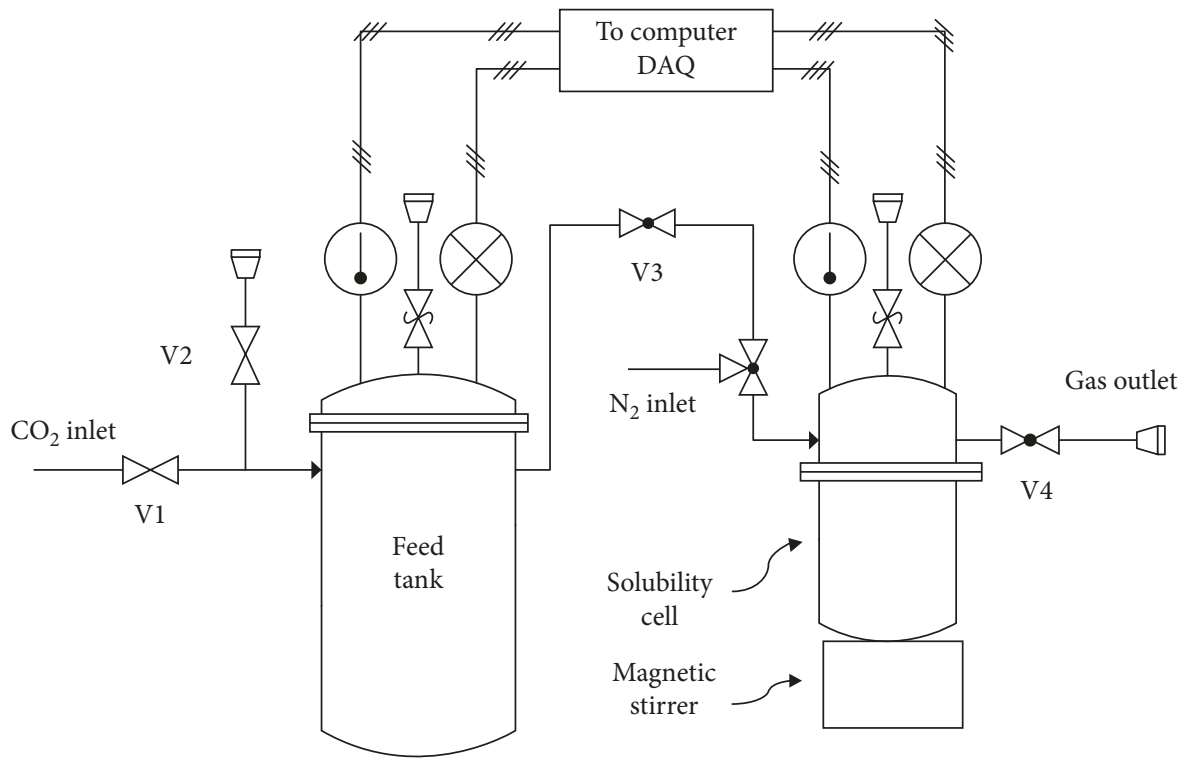

Figure 1: Pressurized reactor system.

$$
\begin{array}{r}
\mathrm{H}_{2} \mathrm{O}+\mathrm{CO}_{2} \stackrel{k_{c}}{\rightleftarrows} \mathrm{H}^{+}+\mathrm{HCO}_{3}^{-} \\
\mathrm{HCO}_{3}{ }^{-} \stackrel{k_{d}}{\rightleftarrows} \mathrm{H}^{+}+\mathrm{CO}_{3}^{2-} \\
\mathrm{H}_{2} \mathrm{O} \stackrel{k_{e}}{\rightleftarrows} \mathrm{H}^{+}+\mathrm{OH}^{-} \\
\mathrm{KOH} \stackrel{k_{f}}{\rightleftarrows} \mathrm{K}^{+}+\mathrm{OH}^{-}
\end{array}
$$

The equilibrium constants, $k_{a}-\mathrm{k}_{\mathrm{f}}$, for reactions (5)-(10) are given as

$$
\begin{aligned}
& k_{a}=\frac{\left[\mathrm{RR}^{-} \mathrm{NH}\right]\left[\mathrm{H}^{+}\right]}{\left[\mathrm{RR}^{-} \mathrm{NH}_{2}^{+}\right]}, \\
& k_{b}=\frac{\left[\mathrm{RR}^{-} \mathrm{NH}\right]\left[\mathrm{HCO}_{3}^{-}\right]}{\left[\mathrm{RR}^{-} \mathrm{NCOO}^{-}\right]}, \\
& k_{c}=\frac{\left[\mathrm{HCO}_{3}^{-}\right]\left[\mathrm{H}^{+}\right]}{\left[\mathrm{CO}_{2}\right]}, \\
& k_{d}=\frac{\left[\mathrm{CO}_{3}^{2-}\right]\left[\mathrm{H}^{+}\right]}{\left[\mathrm{HCO}_{3}^{-}\right]} \\
& k_{e}=\left[\mathrm{OH}^{-}\right]\left[\mathrm{H}^{+}\right] \\
& k_{f}=\frac{\left[\mathrm{OH}^{-}\right]\left[\mathrm{K}^{+}\right]}{\left[\mathrm{KOH}^{2}\right.} .
\end{aligned}
$$

Moreover, balances for reactions given in (5)-(10) are given as follows:

Amino acid balance:

$$
\left[A_{\mathrm{MT}}\right]=\left[\mathrm{RR}^{-} \mathrm{NH}\right]+\left[\mathrm{RR}^{-} \mathrm{NH}_{2}^{+}\right]+\left[\mathrm{RR}^{-} \mathrm{NCOO}^{-}\right]
$$

$$
\begin{aligned}
& \mathrm{CO}_{2} \text { balance: } \\
& \alpha\left[A_{\mathrm{MT}}\right]=\left[\mathrm{CO}_{2}\right]+\left[\mathrm{HCO}_{3}^{-}\right]+\left[\mathrm{CO}_{3}{ }^{2-}\right]+\left[\mathrm{RR}^{-} \mathrm{NCOO}^{-}\right]
\end{aligned}
$$

Electroneutrality balance:

$$
\begin{aligned}
{\left[\mathrm{H}^{+}\right]+\left[\mathrm{K}^{+}\right]=} & {\left[\mathrm{OH}^{-}\right]+\left[\mathrm{HCO}_{3}{ }^{-}\right]+2\left[\mathrm{CO}_{3}{ }^{2-}\right] } \\
& +2\left[\mathrm{RR}^{-} \mathrm{NCOO}^{-}\right]+\left[\mathrm{RR}^{-} \mathrm{NH}\right]
\end{aligned}
$$

The potassium hydroxide value of equilibrium constant is assumed to be very high as compared to other equilibrium constants, $k_{a}$ to $k_{e}$, and the strength of molar for potassium ion, $\left[\mathrm{K}^{+}\right]$, is presumed to be equal to the strength of molar for potassium hydroxide $[\mathrm{KOH}]$. Therefore, value of $\left[\mathrm{K}^{+}\right]$is known. The solution and rearrangement of equations (11)-(17) and (19) yield the equation of polynomial given below:

$$
A\left[\mathrm{H}^{+}\right]^{5}+B\left[\mathrm{H}^{+}\right]^{4}+C\left[\mathrm{H}^{+}\right]^{3}+D\left[\mathrm{H}^{+}\right]^{2}+E\left[\mathrm{H}^{+}\right]+F=0,
$$

where

$$
\begin{aligned}
A= & k_{b x}, \\
B= & k_{b x}\left[\mathrm{~K}^{+}\right]+k_{a x} k_{b x}, \\
C= & k_{a x} k_{b x}\left[\mathrm{~K}^{+}\right]+k_{a x} k_{c}\left[\mathrm{CO}_{2}\right]-k_{b x} k_{c}\left[\mathrm{CO}_{2}\right] \\
& -k_{b x} k_{e}-k_{a x} k_{b x}\left[A_{\mathrm{MT}}\right], \\
D= & k_{a x} k_{c}\left[\mathrm{CO}_{2}\right]\left[\mathrm{K}^{+}\right]-2 k_{a x} k_{c}\left[\mathrm{CO}_{2}\right]\left[A_{\mathrm{MT}}\right] \\
& -k_{a x} k_{b x} k_{c} k_{a x} k_{b x} k_{e}-2 k_{b x} k_{c} k_{d}\left[\mathrm{CO}_{2}\right], \\
E= & -k_{a x} k_{c}^{2}\left[\mathrm{CO}_{2}\right]^{2}-k_{a x} k_{c} k_{e}\left[\mathrm{CO}_{2}\right] \\
& -2 k_{a x} k_{b x} k_{c} k_{d}\left[\mathrm{CO}_{2}\right], \\
F= & -2 k_{a x} k_{c}^{2} k_{d}\left[\mathrm{CO}_{2}\right]^{2} .
\end{aligned}
$$


The value of hydrogen ion concentration, $\left[\mathrm{H}^{+}\right]$, was determined within the range of $10^{-5}$ to $10^{-12}$, according to the relevancy of $\mathrm{pH}$ value of HisK solutions and solved by equation (20). The carbon dioxide loading in the aqueous HisK solution thereby can be calculated based on the following equation:

$$
\alpha=\frac{\left(\left[\mathrm{CO}_{2}\right]+\left(k_{c}\left[\mathrm{CO}_{2}\right] /\left[\mathrm{H}^{+}\right]\right)+\left(k_{c} k_{d}\left[\mathrm{CO}_{2}\right] /\left[\mathrm{H}^{+}\right]^{2}\right)+\left[\mathrm{RR}^{-} \mathrm{NCOO}^{-}\right]\right)}{\left[A_{\mathrm{MT}}\right]},
$$

where the value of $\left[\mathrm{RR}^{-} \mathrm{NCOO}^{-}\right]$is governed by the equation as follows:

$$
\mathrm{RR}^{-} \mathrm{NCOO}^{-}=\frac{\left\{k_{c}\left[\mathrm{~K}^{+}\right]\left[\mathrm{CO}_{2}\right]\left[\mathrm{H}^{+}\right]^{2}+k_{c}\left[\mathrm{CO}_{2}\right]\left[\mathrm{H}^{+}\right]^{3}-k_{c}^{2}\left[\mathrm{CO}_{2}\right]^{2}\left[\mathrm{H}^{+}\right]-k_{c} k_{e}\left[\mathrm{CO}_{2}\right]\left[\mathrm{H}^{+}\right]-2 k_{c}^{2} k_{d}\left[\mathrm{CO}_{2}\right]^{2}\right\}}{k_{b x}\left[\mathrm{H}^{+}\right]^{3}+2 k_{c}\left[\mathrm{CO}_{2}\right]\left[\mathrm{H}^{+}\right]^{2}} .
$$

3.2. Modified Kent-Eisenberg Model Parameters for Absorption of Carbon Dioxide in Aqueous Potassium Histidinate Solution (HisK). Henry's law equation given below is used in the model of modified Kent and Eisenberg for determination of carbon dioxide value in the liquid phase:

$$
\left[\mathrm{CO}_{2}\right]=\frac{P_{\mathrm{CO}_{2}}}{H_{\mathrm{CO}_{2}}} .
$$

On the other hand, the values of equilibrium constants in equations (7)-(10) are obtained from published literatures and calculated based on

$$
k_{i}=\exp \left(\frac{a_{i}}{T+b_{i} \ln T+c_{i}}\right) .
$$

From the equation above, the value of factors from $a_{i}$ to $c_{i}$ is tabulated in Table 3 . The values of apparent equilibrium constants for amino acid, $k_{a x}$ and $k_{b x}$, are regressed to the experimental data.

The regressed values of $k_{a}$ and $k_{b}$ in this work are represented by a set of apparent equilibrium constants given in [41]:

$$
\begin{aligned}
& k_{a x}=k_{a} f_{a}, \\
& k_{b x}=k_{b} f_{b},
\end{aligned}
$$

where the values of $k_{a}$ and $k_{b}$ are determined similarly as equilibrium constants given in Table 3 , on the basis of equation (25). The regressed parameters for both $k_{a}$ and $k_{b}$ are tabulated in Table 4.

Moreover, the values of correction factors, $f_{a}$ and $f_{b}$, are determined by

$$
\begin{aligned}
& f_{a}=\exp \left(s_{1}\left[A_{\mathrm{MT}}\right]+s_{2} P_{\mathrm{CO}_{2}}+s_{3}\left[A_{\mathrm{MT}}\right]^{2}\right), \\
& f_{b}=\exp \left(s_{4}\left[A_{\mathrm{MT}}\right]+s_{5} P_{\mathrm{CO}_{2}}+s_{6}\left[A_{\mathrm{MT}}\right]^{2}\right) .
\end{aligned}
$$

The values of correction parameters for $f_{a}$ and $f_{b}$ are given in Table 5.

\section{Results and Discussion}

The experimental equilibrium $\mathrm{CO}_{2}$ loadings in $1 \mathrm{M}$ and 2.5 M aqueous HisK solutions are presented in Table 6.
With increase in pressure, the solubility of carbon dioxide increases, whereas increase in temperature leads to decrease in loading values. An overall increase in carbon dioxide solubility is seen with increase of the HisK solvent concentration. However, the individual values of gas loading are reduced with increase in solvent concentration, since the HisK concentration appears in the denominator of loading equation as defined in equation (4). Moreover, the trend of the carbon dioxide loadings with respect to pressure, temperature, and concentration was congruent with the common understanding $[7,10,29,34,42,43]$. Additionally, the exothermic reaction of $\mathrm{CO}_{2}$ with $\mathrm{HisK}$ creates a further increase in temperature, leading to a lower loading of $\mathrm{CO}_{2}$ [44]. From the table below, it can also be seen that carbon dioxide loadings in HisK solutions were significant with maximum values reaching 2.399 moles of $\mathrm{CO}_{2}$ per mole of HisK solvent at equilibrium partial pressure of $\mathrm{CO}_{2}(3901 \mathrm{kPa})$.

Additionally, the behaviour of experimental equilibrium $\mathrm{CO}_{2}$ loading data and literature data of monoethanolamine (MEA) are studied and observed. Figure 2 shows the behaviour of carbon dioxide loadings in 1 molar MEA and 1 molar HisK solutions. Similarly, Figure 3 presents the behaviour of carbon dioxide loadings in 2.5 molar MEA and 2.5 molar HisK solutions. Graphical analysis based on Figures 2 and 3 shows that the $\mathrm{CO}_{2}$ loading of HisK is superior to that of MEA. As seen in Figure 2, HisK exhibits very high absorptive capacity than that of MEA at lower temperature $(313.15 \mathrm{~K})$. Contrarily, the carbon dioxide loadings at $353.15 \mathrm{~K}$ are similar to MEA. This means that HisK solutions can absorb more carbon dioxide per mole of solvent. Hence, more carbon dioxide is taken up the absorber section of the carbon dioxide separation system and can be stripped easily in the stripper section with same equilibrium loading. Additionally, based on Figure 3, HisK shows better $\mathrm{CO}_{2}$ absorption at high temperature ( $353.15 \mathrm{~K})$ than MEA, which further strengthens its potential for carbon dioxide $a b-$ sorption and stripping in respective sections. This provides a larger window of absorptive potential (the amount of carbon dioxide transferred from absorption section to a stripping section of a carbon dioxide capture plant), where the HisK solutions are capable of carrying more carbon dioxide gas per cycle of carbon dioxide removal system than MEA, provided that the kinetics of both systems are deemed equal. 
TABLE 3: Values of constants for equation (25).

\begin{tabular}{lcccc}
\hline Equilibrium constant & $a$ & $b$ & $c$ & Reference \\
\hline$k_{c}$ & -12092.1 & -36.7816 & 235.482 & {$[40]$} \\
$k_{d}$ & -1243.7 & -35.4819 & 220.067 & {$[40]$} \\
$k_{e}$ & -13445.9 & -22.4773 & 140.932 & {$[40]$} \\
\hline
\end{tabular}

TABLE 4: Values of constants $k_{a}$ and $k_{b}$ for equations (25) and (26).

\begin{tabular}{lcccc}
\hline \multirow{2}{*}{ Amino acid salt } & \multicolumn{2}{c}{ Equilibrium constant for deprotonation, $k_{a}$} & \multicolumn{2}{c}{ Equilibrium constant for carbamate reversion, $k_{b}$} \\
& $a_{i}$ & $c_{i}$ & $a_{i}$ & $c_{i}$ \\
\hline HisK & -20325.2711 & -29.5371 & -8306.3479 & -46.2272 \\
\hline
\end{tabular}

TABLE 5: Values of constants $f_{a}$ and $f_{b}$ for equations (28) and (29).

\begin{tabular}{lcccccc}
\hline \multirow{2}{*}{ Amino acid salt } & \multicolumn{2}{c}{ Correction parameter for deprotonation, $f_{a}$} & \multicolumn{3}{c}{ Correction parameter for carbamate reversion, $f_{b}$} \\
& $s_{1}$ & $s_{2}$ & $s_{3}$ & $s_{4}$ & $s_{5}$ \\
\hline HisK & 1.1343 & -0.0900 & -0.0139 & -0.5817 & 0.0013 \\
\hline
\end{tabular}

TABLE 6: Experimental carbon dioxide solubility in aqueous potassium salt of $L$-histidine.

\begin{tabular}{|c|c|c|c|c|c|c|}
\hline \multirow{3}{*}{ Concentration (M) } & \multicolumn{6}{|c|}{ Temperature (K) } \\
\hline & \multicolumn{2}{|r|}{313.15} & \multicolumn{2}{|c|}{333.15} & \multicolumn{2}{|r|}{353.15} \\
\hline & $P(\mathrm{kPa})$ & $\alpha\left(\right.$ mol. $\left.\left(\mathrm{mol} \cdot \mathrm{HisK}^{-1}\right)\right)$ & $P(\mathrm{kPa})$ & $\alpha\left(\right.$ mol. $\left.\left(\mathrm{mol} \cdot \mathrm{HisK}^{-1}\right)\right)$ & $P(\mathrm{kPa})$ & $\alpha\left(\mathrm{mol} .\left(\mathrm{mol} \cdot \mathrm{HisK}^{-1}\right)\right)$ \\
\hline \multirow{9}{*}{1.0} & 154.00 & 1.1007 & 392.60 & 0.8512 & 360.30 & 0.6319 \\
\hline & 511.00 & 1.2621 & 623.90 & 1.0293 & 621.60 & 0.7239 \\
\hline & 1001.0 & 1.5029 & 1011.7 & 1.1899 & 1023.4 & 0.7924 \\
\hline & 1499.0 & 1.7222 & 1448.9 & 1.2419 & 1434.9 & 0.9988 \\
\hline & 2055.0 & 1.8000 & 1923.9 & 1.2533 & 2021.6 & 1.1379 \\
\hline & 2418.0 & 1.9153 & 2605.1 & 1.3601 & 2641.1 & 1.1405 \\
\hline & 2801.0 & 2.0897 & 2992.6 & 1.4968 & 3123.5 & 1.2897 \\
\hline & 3450.0 & 2.2356 & 3523.9 & 1.6111 & 3555.8 & 1.4457 \\
\hline & 3901.0 & 2.3990 & 4192.6 & 1.8089 & 4078.9 & 1.5379 \\
\hline \multirow{9}{*}{2.5} & 205.10 & 0.6782 & 352.60 & 0.5996 & 230.10 & 0.4279 \\
\hline & 502.60 & 0.6990 & 523.90 & 0.6665 & 455.10 & 0.4659 \\
\hline & 911.40 & 0.8031 & 942.60 & 0.7865 & 1136.4 & 0.5843 \\
\hline & 1432.6 & 0.9276 & 1861.4 & 0.8991 & 1436.4 & 0.6076 \\
\hline & 1972.6 & 1.1050 & 2286.4 & 0.9115 & 1905.10 & 0.7687 \\
\hline & 2423.9 & 1.1330 & 2792.6 & 0.9672 & 2361.4 & 0.7968 \\
\hline & 2837.5 & 1.1626 & 3155.1 & 0.9803 & 2917.6 & 0.8400 \\
\hline & 3398.9 & 1.2898 & 3448.9 & 1.0000 & 3598.9 & 0.9025 \\
\hline & 3930.1 & 1.3554 & 3905.1 & 1.1464 & 3923.9 & 0.9982 \\
\hline
\end{tabular}

The standard uncertainties: $u(T)=0.1 \mathrm{~K} ; u(P)=1.25 \mathrm{kPa} ; u(M)$ for 1 and 2.5 molar concentration is $0.010 \mathrm{M}$ and $0.004 \mathrm{M}$, respectively, whereas $u_{c}(\alpha)=0.082$.

For example, the carbon dioxide loading for 1 molar aqueous potassium salt of $L$-histidine at $313.15 \mathrm{~K}$ and a pressure of $1000 \mathrm{kPa}$ is $1.503 \mathrm{~mol} / \mathrm{mol}$, whereas the carbon dioxide loading in 1 molar MEA at similar process conditions is $1.143 \mathrm{~mol} / \mathrm{mol}$. This means that HisK solutions can pick 0.36 more moles of carbon dioxide than MEA at absorber conditions. Similarly, the carbon dioxide loading for 1 molar aqueous potassium salt of $L$-histidine at $353.15 \mathrm{~K}$ and a pressure of $360 \mathrm{kPa}$ is $0.632 \mathrm{~mol} / \mathrm{mol}$, whereas the carbon dioxide loading in 1 molar MEA at almost similar process conditions $(316 \mathrm{kPa}$ than $360 \mathrm{kPa})$ is $0.772 \mathrm{~mol} / \mathrm{mol}$. This means that, at stripping conditions (assuming that stripper operates at $353.15 \mathrm{~K}$ ), HisK solutions will be less loaded at equilibrium than the MEA (quantitatively by a difference of
$0.14 \mathrm{~mol} / \mathrm{mol})$. Eventually, HisK solutions can separate 0.871 moles of carbon dioxide per mole of solvent per cycle, whereas MEA can only transfer 0.371 moles at similar process conditions.

Furthermore, better absorptive potential also allows the stripping section to be operated at lower temperature $(353.15 \mathrm{~K})$ as compared to MEA (>373.15 K), resulting in lower energy penalty, reducing thermal degradation of solvent, and reducing the fugitive emission of the solvent.

On the other hand, Figure 4 illustrates the behaviour of carbon dioxide loadings in 1 molar potassium salt of lysine (LysK) with 1 molar HisK solutions, whereas Figure 5 presents the behaviour of carbon dioxide loadings in 2.5 molar LysK and 2.5 molar HisK solutions. It can be seen 


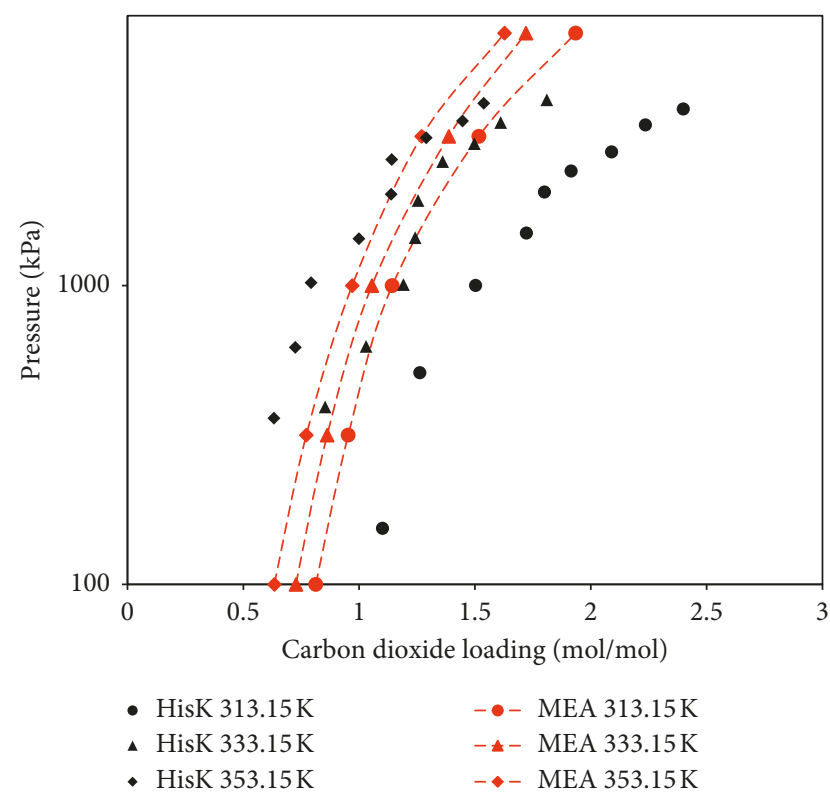

FIgURE 2: Experimental solubility behaviour of carbon dioxide in $1 \mathrm{M}$ aqueous potassium salt of $L$-histidine and data of $1 \mathrm{M}$ monoethanolamine [45].

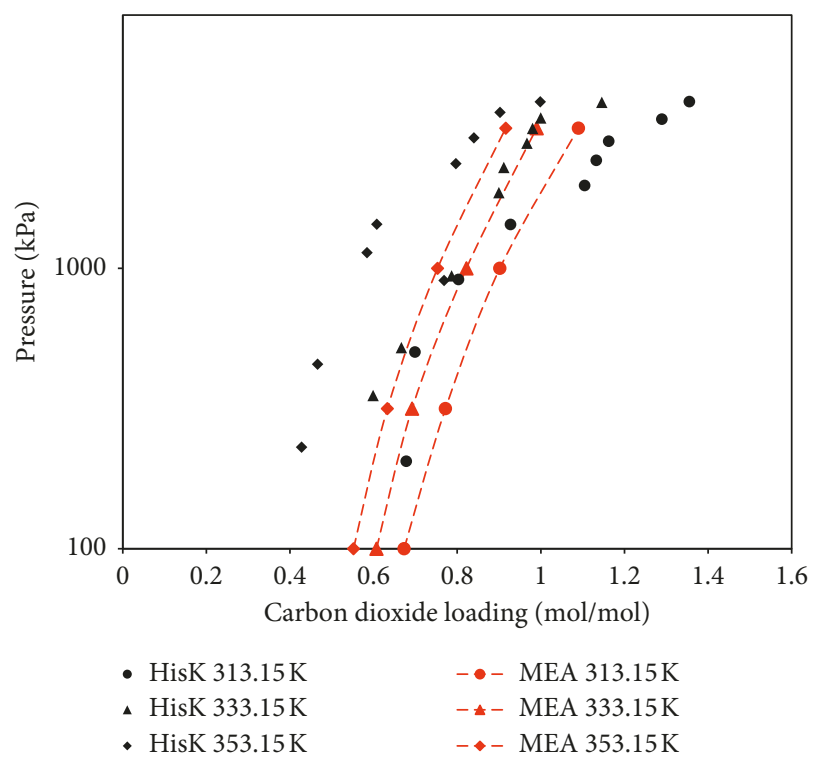

FIgURE 3: Experimental solubility behaviour of carbon dioxide in $2.5 \mathrm{M}$ aqueous potassium salt of $L$-histidine and data of 2.5 monoethanolamine [45].

from these figures that carbon dioxide solubility in HisK solutions is higher when compared to LysK solutions at $313.15 \mathrm{~K}$ and almost similar at $353.15 \mathrm{~K}$. Although amino acid salt of lysine was previously observed to have higher $\mathrm{CO}_{2}$ absorption capacity than others in the group $[7,9,46-48]$, it is explicated in this study that amino acid salt of histidine offered a comparable absorption capacity with the lysine. This can be attributed to the presence of an amide bond in the R-structure of $L$-histidine that presumably allows great capture of the carbon dioxide molecule. This means that $L$-histidine has comparatively high absorptive

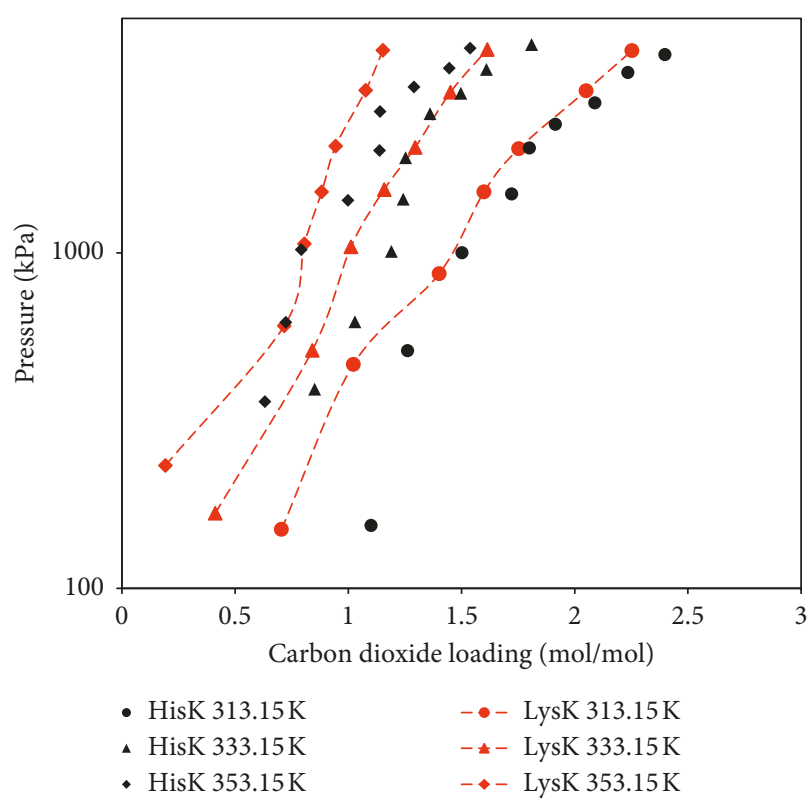

Figure 4: Experimental solubility behaviour of carbon dioxide in $1 \mathrm{M}$ aqueous potassium salt of $L$-histidine and data of $1 \mathrm{M}$ aqueous potassium salt of lysinate [7].

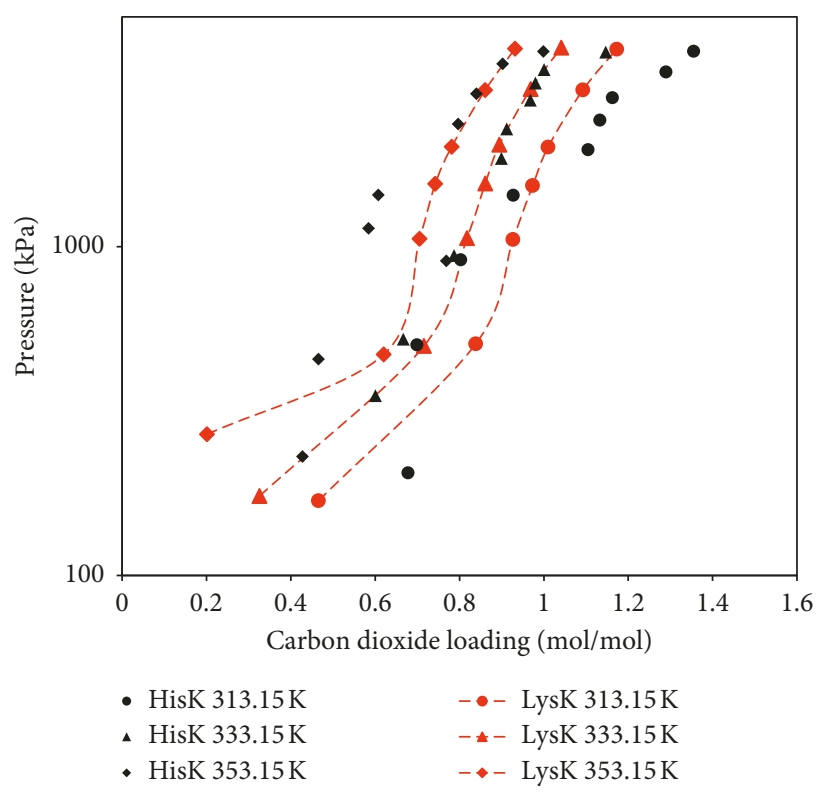

FIGURE 5: Experimental solubility behaviour of carbon dioxide in $2.5 \mathrm{M}$ aqueous potassium salt of $L$-histidine and data of $2.5 \mathrm{M}$ aqueous potassium salt of lysinate [7].

potential with lysine, allowing great separation of carbon dioxide in the carbon dioxide removal system. It is expected that the presence of amide bond shall also contribute to better kinetic rate for HisK solutions, since its structure resembles with piperazine-type promoters.

The modified Kent-Eisenberg model was used to correlate the experimental results of this study. Figure 6 shows the correlated $\mathrm{CO}_{2}$ loading against the experimental results for carbon dioxide solubility in 1 molar HisK solutions. Similarly, Figure 7 illustrates the correlated $\mathrm{CO}_{2}$ loading 


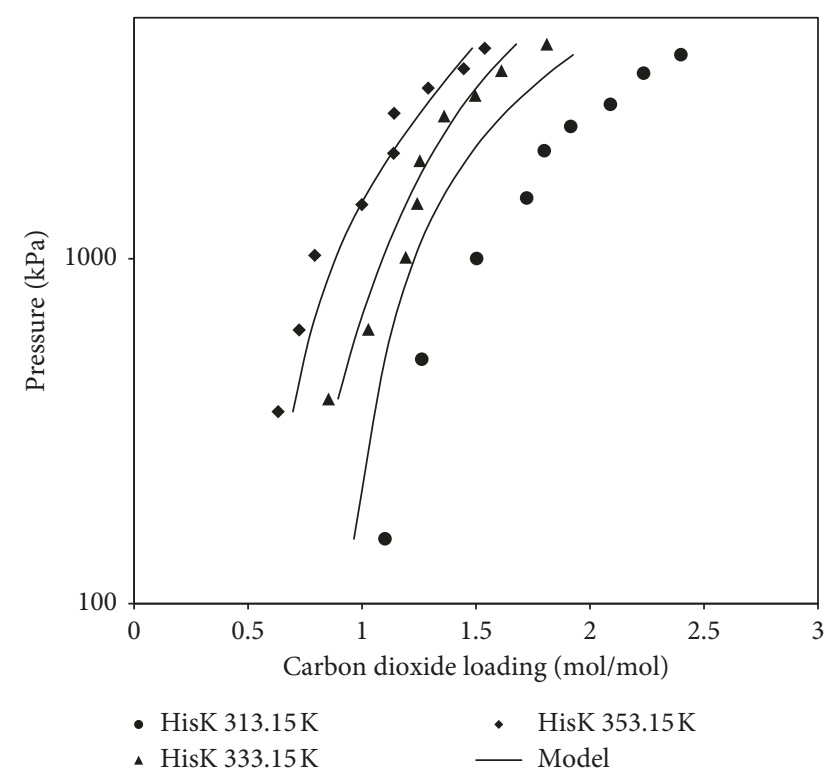

FIGURE 6: Correlation of modified Kent-Eisenberg model against the experimental solubility of carbon dioxide in $1 \mathrm{M}$ aqueous potassium salt of $L$-histidine (HisK).

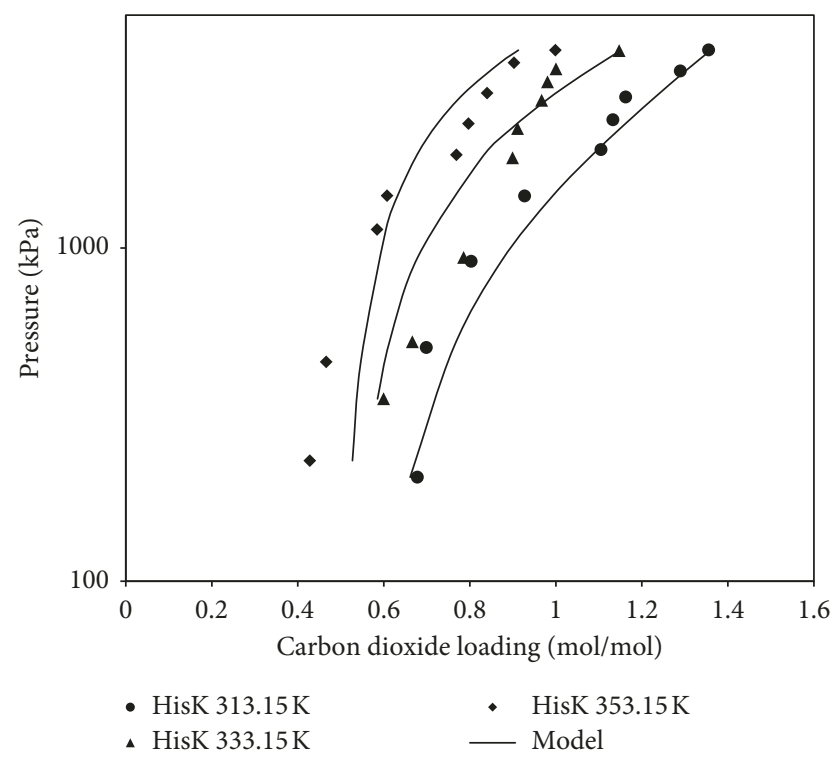

Figure 7: Correlation of modified Kent-Eisenberg model against the experimental solubility of carbon dioxide in $2.5 \mathrm{M}$ aqueous potassium salt of $L$-histidine (HisK).

against the experimental results for carbon dioxide solubility in 2.5 molar HisK solutions. The carbon dioxide loadings correlated by the model are slightly underpredicted at the low temperature $(313.15 \mathrm{~K})$ and overpredicted at the high temperature $(353.15 \mathrm{~K})$. This is attributed to the regression of temperature-dependent correction parameters $\left(a_{i}\right.$ and $\left.c_{i}\right)$ for equilibrium constants for deprotonation and carbamate formation and can be further improved by adding more correction factors by taking the square of temperature as the correction value. However, this will induce greater complexity in the model and tend to override the contribution of concentration and pressure-based correction factors. With respect to pressure, the model results are satisfactory as all the values along the pressure curve are well correlated. Similarly, the effect of concentration on the correlated values is well within the nonideality level assumed for the application of the Kent-Eisenberg model. Overall, the model results are in good agreement with the experimental $\mathrm{CO}_{2}$ loading data. The results of the model are within the experimental errors of this study. The average absolute relative error (AARE\%) was determined by

$$
\operatorname{AARE} \%=\left(\frac{\alpha_{\text {calc }}-\alpha_{\text {expt }}}{\alpha_{\text {expt }}}\right) \cdot 100 \% .
$$

The AARE\% between the model predicted and experimental results was found to be $7.87 \%$, indicating that the modified Kent-Eisenberg model shows satisfactory results and able to accurately predict the solubility of carbon dioxide at a wide range of process conditions with minimum computational complicacy.

\section{Conclusions}

In this study, the VLE data of carbon dioxide-loaded aqueous solutions of potassium salt of $L$-histidine were measured using the HP-VLE apparatus. The experimental study was performed for a wide range of process parameters (temperature of 313.15 to $353.15 \mathrm{~K}$, pressure of 150 to $4000 \mathrm{kPa}$, and solvent concentration of 1 and 2.5 molar). The experimental results show that the HisK solutions exhibited high absorption capacity of carbon dioxide, with intrinsic advantages of being negligibly volatile, resistant to degradation, and environmentally friendly. Moreover, a high carbon dioxide solubility will limit the amount of solvent needed to capture a certain amount of carbon dioxide, thus reducing the amount of used pump power as well as decrease the heat requirements for regeneration $[49,50]$.

On the other hand, the HisK solutions also offered comparatively better carbon dioxide absorption potential than conventional solvent like MEA and potential amino acid salt solution like potassium lysinate. The experimental results provided a unique insight into the phase equilibrium behaviour of the studied $\mathrm{CO}_{2}+L$-histidine $+\mathrm{H}_{2} \mathrm{O}$ systems. The tested system has the ability to capture carbon dioxide and is a promising green solvent that can replace conventional alkanolamines. Moreover, the vapour-liquid equilibrium data for aqueous HisK solutions were correlated by a modified Kent-Eisenberg model. Remarkably, AARE\% of $7.87 \%$ was generated. The model results were in excellent agreement with the experimental data of this study and indicate that the model can be effectually used for accurate prediction of VLE of the said system at other process conditions in simulation studies.

\section{Abbreviations}

$n_{\mathrm{fed}}$ : $\quad$ Number of moles of carbon dioxide fed to the solubility cell

$n_{1}$ : $\quad$ Number of moles of carbon dioxide initially in the feed tank 


\begin{tabular}{|c|c|}
\hline$n_{2}:$ & $\begin{array}{l}\text { Number of moles of carbon dioxide after } \\
\text { feeding to the solubility cell }\end{array}$ \\
\hline$n_{\mathrm{abs}}:$ & $\begin{array}{l}\text { Number of moles of carbon dioxide absorbed } \\
\text { in the amino acid solution }\end{array}$ \\
\hline$n_{\text {res }}:$ & $\begin{array}{l}\text { Residual number of moles of carbon dioxide } \\
\text { in the solubility cell }\end{array}$ \\
\hline$n_{\text {aminoacid }}:$ & $\begin{array}{l}\text { Unreacted number of moles of amino acid } \\
\text { solution fed to the solubility cell }\end{array}$ \\
\hline$P_{\text {resCO }_{2}}:$ & $\begin{array}{l}\text { Partial pressure of carbon dioxide in the } \\
\text { solubility cell at equilibrium }\end{array}$ \\
\hline$P_{\mathrm{T}}:$ & $\begin{array}{l}\text { Total residual pressure in the solubility cell at } \\
\text { equilibrium }\end{array}$ \\
\hline$P_{\mathrm{N}}:$ & $\begin{array}{l}\text { Partial pressure of nitrogen in the solubility } \\
\text { cell at equilibrium }\end{array}$ \\
\hline$P_{\mathrm{W}}:$ & $\begin{array}{l}\text { Partial pressure of water in the solubility cell } \\
\text { at equilibrium }\end{array}$ \\
\hline$P_{\mathrm{A}}:$ & $\begin{array}{l}\text { Partial pressure of amino acid in the solubility } \\
\text { cell at equilibrium }\end{array}$ \\
\hline$A_{\mathrm{MT}}:$ & $\begin{array}{l}\text { Total amino acid salt concentration } \\
\text { (mole/litre) }\end{array}$ \\
\hline $\mathrm{CO}_{2}$ : & Carbon dioxide \\
\hline $\mathrm{CO}_{3}{ }^{2-}:$ & Carbonate \\
\hline$f_{a}, f_{b}:$ & $\begin{array}{l}\text { Correction parameters for the modified } \\
\text { KE model }\end{array}$ \\
\hline $\mathrm{H}_{2} \mathrm{O}:$ & Water \\
\hline $\mathrm{H}^{+}:$ & Hydrogen ion \\
\hline $\mathrm{HCO}_{3}{ }^{-}:$ & Bicarbonate \\
\hline$H_{\mathrm{CO}_{2}}:$ & $\begin{array}{l}\text { Henry's constant for carbon dioxide } \\
\text { (atm.litre/mole) }\end{array}$ \\
\hline$P_{\mathrm{CO}_{2}}:$ & Partial pressure of carbon dioxide $(\mathrm{kPa})$ \\
\hline $\mathrm{KOH}:$ & Potassium hydroxide \\
\hline $\mathrm{K}^{+}:$ & Potassium ion \\
\hline$k_{a}:$ & $\begin{array}{l}\text { Equilibrium constant of deprotonation of } \\
\text { amino acid for the modified KE model }\end{array}$ \\
\hline$k_{b}:$ & $\begin{array}{l}\text { Equilibrium constant of carbamate hydrolysis } \\
\text { of amino acid for the modified KE model }\end{array}$ \\
\hline$k_{a x}:$ & $\begin{array}{l}\text { Apparent equilibrium constant of } \\
\text { deprotonation of amino acid for the modified } \\
\text { KE model }\end{array}$ \\
\hline$k_{b x}:$ & $\begin{array}{l}\text { Apparent equilibrium constant of carbamate } \\
\text { hydrolysis of amino acid for the modified KE } \\
\text { model }\end{array}$ \\
\hline$k_{c}:$ & $\begin{array}{l}\text { Equilibrium constant of dissociation of } \\
\text { carbon dioxide for the modified KE model }\end{array}$ \\
\hline$k_{d}:$ & $\begin{array}{l}\text { Equilibrium constant of dissociation of } \\
\text { carbon bicarbonate for the modified KE } \\
\text { model }\end{array}$ \\
\hline$k_{e}:$ & $\begin{array}{l}\text { Equilibrium constant of dissociation of water } \\
\text { for the modified } \mathrm{KE} \text { model }\end{array}$ \\
\hline$k_{f}:$ & $\begin{array}{l}\text { Equilibrium constant of dissociation of } \\
\text { potassium hydroxide for the modified KE } \\
\text { model }\end{array}$ \\
\hline $\mathrm{OH}^{-}:$ & Hydroxide ion \\
\hline$P_{\mathrm{CO}_{2}}:$ & $\begin{array}{l}\text { Pressure of carbon dioxide in vapour } \\
\text { phase }(\mathrm{kPa})\end{array}$ \\
\hline $\mathrm{RR}^{-} \mathrm{NH}:$ & Free amino acid \\
\hline $\mathrm{RR}^{-} \mathrm{NH}_{2}^{+}:$ & Protonated amino acid \\
\hline 1 NeOC & Carbamate ion of amino acid \\
\hline
\end{tabular}

$\begin{array}{ll}s_{1}-\mathrm{s}_{6}: & \begin{array}{l}\text { Adjustable parameters for the modified } \mathrm{KE} \\ \text { model based upon process parameters }\end{array} \\ \alpha: & \begin{array}{l}\text { Carbon dioxide loading, mole of } \mathrm{CO}_{2} / \text { mole of } \\ \text { amine }\end{array} \\ \alpha_{\text {calc }}: & \begin{array}{l}\text { Calculated carbon dioxide loading, mole of } \\ \mathrm{CO}_{2} / \text { mole of amine }\end{array} \\ u(T): & \text { The temperature uncertainty } \\ u(P): & \text { The pressure uncertainty } \\ u(M): & \text { The concentration uncertainty } \\ u_{c}(\alpha): & \text { The combined expanded uncertainty. }\end{array}$

\section{Data Availability}

The data are available upon request from Nor Afaf Syalsabila, Universiti Teknologi PETRONAS, Seri Iskandar, Perak, Malaysia,norafafsyalsabila@gmail.com, +60 011-19637178.

\section{Conflicts of Interest}

The authors declare that they have no conflicts of interest.

\section{Acknowledgments}

The authors are thankful to the Ministry of Higher Education (MOHE), Malaysia, for funding this study under their FRGS grant scheme 0153AB-L24 (2016-2018).

\section{References}

[1] A. L. Kohl and R. B. Nielsen, Gas Purification, Elsevier Gulf, Houston, TX, USA, 1997.

[2] N. MacDowell, N. Florin, A. Buchard et al., "An overview of $\mathrm{CO}_{2}$ capture technologies," Energy \& Environmental Science, vol. 3, no. 11, pp. 1645-1669, 2010.

[3] R. Shao and A. Stangeland, "Amines used in $\mathrm{CO}_{2}$ capturehealth and environmental impacts," Bellona Report, vol. 49, pp. 1-49, 2009.

[4] P. S. Kumar, J. A. Hogendoorn, G. F. Versteeg, and P. H. M. Feron, "Kinetics of the reaction of $\mathrm{CO}_{2}$ with aqueous potassium salt of taurine and glycine," AIChE Journal, vol. 49, no. 1, pp. 203-213, 2003.

[5] J. V. Holst, G. F. Versteeg, D. W. F. Brilman, and J. Hogendoorn, "Kinetic study of $\mathrm{CO}_{2}$ with various amino acid salts in aqueous solution," Chemical Engineering Science, vol. 64, no. 1, pp. 59-68, 2009.

[6] D. M. Muñoz, A. F. Portugal, A. E. Lozano, G. José, and J. de Abajo, "New liquid absorbents for the removal of $\mathrm{CO}_{2}$ from gas mixtures," Energy \& Environmental Science, vol. 2, no. 8, pp. 883-891, 2009.

[7] H. Suleman, A. S. Maulud, and Z. Man, "Carbon dioxide solubility in aqueous potassium lysinate solutions: high pressure data and thermodynamic modeling," Procedia Engineering, vol. 148, pp. 1303-1311, 2016.

[8] B. M. Lerche, E. H. Stenby, and K. Thomsen, $\mathrm{CO}_{2}$ Capture from Flue Gas Using Amino Acid Salt Solutions, Technical University of Denmark, Department of Chemistry, Institut for Kemi, Kongens Lyngby, Denmark, 2012.

[9] S. Shen, Y.-N. Yang, Y. Wang, S. Ren, J. Han, and A. Chen, " $\mathrm{CO}_{2}$ absorption into aqueous potassium salts of lysine and proline: density, viscosity and solubility of $\mathrm{CO}_{2}$," Fluid Phase Equilibria, vol. 399, pp. 40-49, 2015. 
[10] S. Mazinani, R. Ramazani, A. Samsami, A. Jahanmiri, B. Van der Bruggen, and S. Darvishmanesh, "Equilibrium solubility, density, viscosity and corrosion rate of carbon dioxide in potassium lysinate solution," Fluid Phase Equilibria, vol. 396, pp. 28-34, 2015.

[11] Y. Bian and S. Shen, "Modeling of $\mathrm{CO}_{2}$ solubility in aqueous potassium lysinate solutions at post-combustion $\mathrm{CO}_{2}$ capture conditions," IOP Conference Series: Earth and Environmental Science, vol. 68, no. 1, article 012008, 2017.

[12] S. Shen, Y. Zhao, Y. Bian, Y. Wang, H. Guo, and H. Li, " $\mathrm{CO}_{2}$ absorption using aqueous potassium lysinate solutions: vapor-liquid equilibrium data and modelling," The Journal of Chemical Thermodynamics, vol. 115, pp. 209-220, 2017.

[13] Y. Zhao, S. Shen, Y. Bian, Y.-N. Yang, and U. Ghosh, " $\mathrm{CO}_{2}$ solubility in aqueous potassium lysinate solutions at absorber conditions," The Journal of Chemical Thermodynamics, vol. 111, pp. 100-105, 2017.

[14] J.-A. Lim, D. H. Kim, Y. Yoon, S. K. Jeong, K. T. Park, and S. C. Nam, "Absorption of $\mathrm{CO}_{2}$ into aqueous potassium salt solutions of L-alanine and L-proline," Energy \& Fuels, vol. 26, no. 6, pp. 3910-3918, 2012.

[15] M. Majchrowicz and D. Brilman, "Solubility of $\mathrm{CO}_{2}$ in aqueous potassium 1-prolinate solutions-absorber conditions," Chemical Engineering Science, vol. 72, pp. 35-44, 2012.

[16] Y.-T. Chang, R. B. Leron, and M.-H. Li, "Carbon dioxide solubility in aqueous potassium salt solutions of l-proline and dl- $\alpha$-aminobutyric acid at high pressures," ournal of Chemical Thermodynamics, vol. 83, pp. 110-116, 2015.

[17] M. E. Hamzehie and H. Najibi, " $\mathrm{CO}_{2}$ solubility in aqueous solutions of potassium prolinate and (potassium prolinate + 2-amino-2-methyl-1-propanol) as new absorbents," Journal of Natural Gas Science and Engineering, vol. 34, pp. 356-365, $2016 \mathrm{a}$.

[18] U. E. Aronu, H. F. Svendsen, and K. A. Hoff, "Investigation of amine amino acid salts for carbon dioxide absorption," International Journal of Greenhouse Gas Control, vol. 4, no. 5, pp. 771-775, 2010.

[19] D. Kang, S. Park, H. Jo, J. Min, and J. Park, "Solubility of $\mathrm{CO}_{2}$ in amino-acid-based solutions of (potassium sarcosinate), (potassium alaninate + piperazine), and (potassium serinate + piperazine)," Journal of Chemical \& Engineering Data, vol. 58, no. 6, pp. 1787-1791, 2013.

[20] P. H. Feron and N. ten Asbroek, New Solvents Based on Amino-Acid Salts for $\mathrm{CO}_{2}$ Capture from Flue Gases, Elsevier, Amsterdam, Netherlands, 2005.

[21] F. Harris, K. A. Kurnia, M. I. A. Mutalib, and M. Thanapalan, "Solubilities of carbon dioxide and densities of aqueous sodium glycinate solutions before and after $\mathrm{CO}_{2}$ absorption," Journal of Chemical \& Engineering Data, vol. 54, no. 1, pp. 144-147, 2008.

[22] H.-J. Song, S. Lee, S. Maken, J.-J. Park, and J.-W. Park, "Solubilities of carbon dioxide in aqueous solutions of sodium glycinate," Fluid Phase Equilibria, vol. 246, no. 1-2, pp. 1-5, 2006.

[23] A. Portugal, J. Sousa, F. Magalhães, and A. Mendes, "Solubility of carbon dioxide in aqueous solutions of amino acid salts," Chemical Engineering Science, vol. 64, no. 9, pp. 1993-2002, 2009.

[24] F. Harris, K. A. Kurnia, M. I. A. Mutalib, and M. Thanapalan, "Solubilities of carbon dioxide and densities of aqueous sodium glycinate solutions before and after $\mathrm{CO}_{2}$ absorption," Journal of Chemical \& Engineering Data, vol. 54, no. 1, pp. 144-147, 2009.
[25] B. K. Mondal, S. S. Bandyopadhyay, and A. N. Samanta, "VLE of $\mathrm{CO}_{2}$ in aqueous sodium glycinate solution-new data and modeling using Kent-Eisenberg model," International Journal of Greenhouse Gas Control, vol. 36, pp. 153-160, 2015.

[26] M. E. Hamzehie and H. Najibi, "Experimental and theoretical study of carbon dioxide solubility in aqueous solution of potassium glycinate blended with piperazine as new absorbents," Journal of $\mathrm{CO}_{2}$ Utilization, vol. 16, pp. 64-77, 2016.

[27] Z.-W. Chen, R. B. Leron, and M.-H. Li, "Equilibrium solubility of carbon dioxide in aqueous potassium 1-asparaginate and potassium l-glutaminate solutions," Fluid Phase Equilibria, vol. 400, pp. 20-26, 2015.

[28] Y.-T. Chang, R. B. Leron, and M.-H. Li, "Carbon dioxide solubility in aqueous potassium salt solutions of 1-proline and $\mathrm{dl}-\alpha$-aminobutyric acid at high pressures," The Journal of Chemical Thermodynamics, vol. 83, pp. 110-116, $2015 \mathrm{~b}$.

[29] S. Garg, A. Shariff, M. Shaikh, B. Lal, H. Suleman, and N. Faiqa, "Experimental data, thermodynamic and neural network modeling of $\mathrm{CO}_{2}$ solubility in aqueous sodium salt of 1-phenylalanine," Journal of $\mathrm{CO}_{2}$ Utilization, vol. 19, pp. 146-156, 2017.

[30] S. Shen, Y.-N. Yang, Y. Zhao, and Y. Bian, "Reaction kinetics of carbon dioxide absorption into aqueous potassium salt of histidine," Chemical Engineering Science, vol. 146, pp. 76-87, 2016b.

[31] W. Hu and A. Chakma, "Modelling of equilibrium solubility of $\mathrm{CO}_{2}$ and $\mathrm{H}_{2} \mathrm{~S}$ in aqueous amino methyl propanol (AMP) solutions," Chemical Engineering Communications, vol. 94, no. 1, pp. 53-61, 1990.

[32] W. Kritpiphat and P. Tontiwachwuthikul, "New modified Kent-Eisenberg model for predicting carbon dioxide solubility in aqueous 2-amino-2-methyl-1-propanol (AMP) solutions," Chemical Engineering Communications, vol. 144, no. 1, pp. 73-83, 1996.

[33] H. Suleman, A. S. Maulud, and Z. Man, "Review and selection criteria of classical thermodynamic models for acid gas absorption in aqueous alkanolamines," Reviews in Chemical Engineering, vol. 31, no. 6, pp. 599-639, 2015.

[34] H. Suleman, A. S. Maulud, and Z. Man, "Experimental measurement and thermodynamic modeling of the solubility of carbon dioxide in aqueous alkanolamine solutions in the high gas loading region," International Journal of Thermophysics, vol. 37, no. 9, p. 94, 2016b.

[35] H. Suleman, A. S. Maulud, and Z. Man, "Experimental measurement and thermodynamic modeling of the solubility of carbon dioxide in aqueous blends of monoethanolamine and diethanolamine," AIP Conference Proceedings, vol. 1901, no. 1, article 110004, 2017.

[36] I. V. Yakoumis, K. Vlachos, G. M. Kontogeorgis et al., "Application of the LCVM model to systems containing organic compounds and supercritical carbon dioxide," Journal of Supercritical Fluids, vol. 9, no. 2, pp. 88-98, 1996.

[37] K. Magoulas and D. Tassios, "Thermophysical properties of n-alkanes from $\mathrm{C} 1$ to $\mathrm{C} 20$ and their prediction for higher ones," Fluid Phase Equilibria, vol. 56, pp. 119-140, 1990.

[38] R. Span and W. Wagner, "A new equation of state for carbon dioxide covering the fluid region from the triple-point temperature to $1100 \mathrm{~K}$ at pressures up to $800 \mathrm{MPa}$," Journal of Physical and Chemical Reference Data, vol. 25, no. 6, pp. 1509-1596, 1996.

[39] D. E. Penny and T. J. Ritter, "Kinetic study of the reaction between carbon dioxide and primary amines," Journal of the Chemical Society, Faraday Transactions 1: Physical Chemistry in Condensed Phases, vol. 79, no. 9, pp. 2103-2109, 1983. 
[40] T. Edwards, G. Maurer, J. Newman, and J. Prausnitz, "Vaporliquid equilibria in multicomponent aqueous solutions of volatile weak electrolytes," AIChE Journal, vol. 24, no. 6, pp. 966-976, 1978.

[41] M. Haji-Sulaiman, M. Aroua, and A. Benamor, "Analysis of equilibrium data of $\mathrm{CO}_{2}$ in aqueous solutions of diethanolamine (DEA), methyldiethanolamine (MDEA) and their mixtures using the modified Kent Eisenberg model," Chemical Engineering Research and Design, vol. 76, no. 8, pp. 961-968, 1998.

[42] H. A. Haider, R. Yusoff, and M. Aroua, "Equilibrium solubility of carbon dioxide in 2 (methylamino) ethanol," Fluid Phase Equilibria, vol. 303, no. 2, pp. 162-167, 2011.

[43] B. K. Mondal, S. S. Bandyopadhyay, and A. N. Samanta, "VLE of $\mathrm{CO}_{2}$ in aqueous sodium glycinate solution-new data and modeling using Kent-Eisenberg model," International Journal of Greenhouse Gas Control, vol. 36, pp. 153-160, 2015b.

[44] V. Salazar, Y. Sánchez-Vicente, C. Pando, J. A. Renuncio, and A. Cabañas, "Enthalpies of absorption of carbon dioxide in aqueous sodium glycinate solutions at temperatures of (313.15 and 323.15) K," Journal of Chemical \& Engineering Data, vol. 55, no. 3, pp. 1215-1218, 2009.

[45] J. I. Lee, F. D. Otto, and A. E. Mather, "Equilibrium between carbon dioxide and aqueous monoethanolamine solutions," Journal of Applied Chemistry and Biotechnology, vol. 26, no. 1, pp. 541-549, 1976.

[46] B. M. Lerche, K. Thomsen, and E. H. Stenby, "Amino acid salt solutions as solvents in $\mathrm{CO}_{2}$ capture from flue gas: $\mathrm{CO}_{2}$ loading capacity and precipitation," in Proceedings of the 6th Trondheim Conference on CO2 Capture, Transport and Storage, Trondheim, Norway, June 2011.

[47] R. Ramezani, S. Mazinani, R. Di Felice, and B. Van der Bruggen, "Experimental and correlation study of corrosion rate, absorption rate and $\mathrm{CO}_{2}$ loading capacity in five blend solutions as new absorbents for $\mathrm{CO}_{2}$ capture," Journal of Natural Gas Science and Engineering, vol. 45, pp. 599-608, 2017.

[48] S. Shen, Y.-N. Yang, Y. Bian, and Y. Zhao, "Kinetics of $\mathrm{CO}_{2}$ absorption into aqueous basic amino acid salt: potassium salt of lysine solution," Environmental Science \& Technology, vol. 50, no. 4, pp. 2054-2063, 2016 a.

[49] V. Darde, $\mathrm{CO}_{2}$ capture using aqueous ammonia, Ph.D. thesis, Department of Chemical and Biochemical Engineering, Technical University of Denmark, Kongens Lyngby, Denmark, 2011.

[50] J. Gabrielsen, " $\mathrm{CO}_{2}$ capture from coal fired power plants," in Graduate Schools Yearbook 2005, p. 61, DTU Orbit-The Research Information System, Kongens Lyngby, Denmark, 2005. 


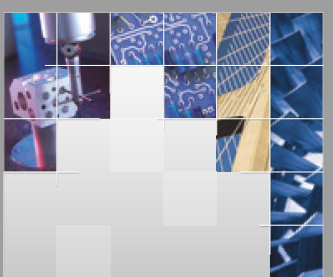

\section{Enfincering}
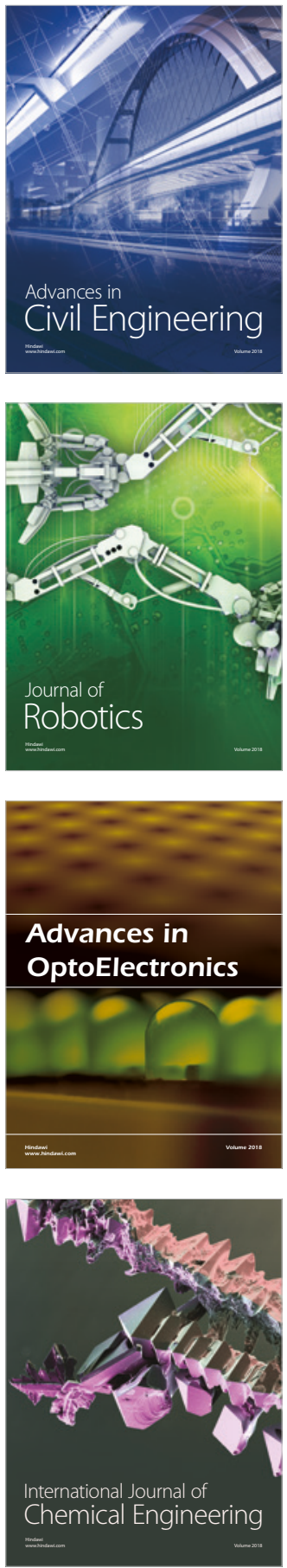

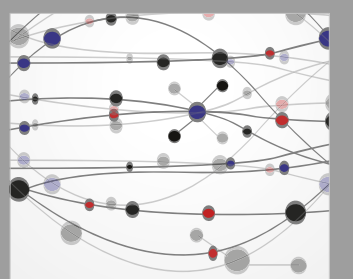

\section{Rotating \\ Machinery}

The Scientific World Journal

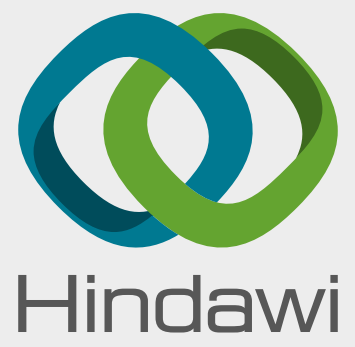

Submit your manuscripts at

www.hindawi.com
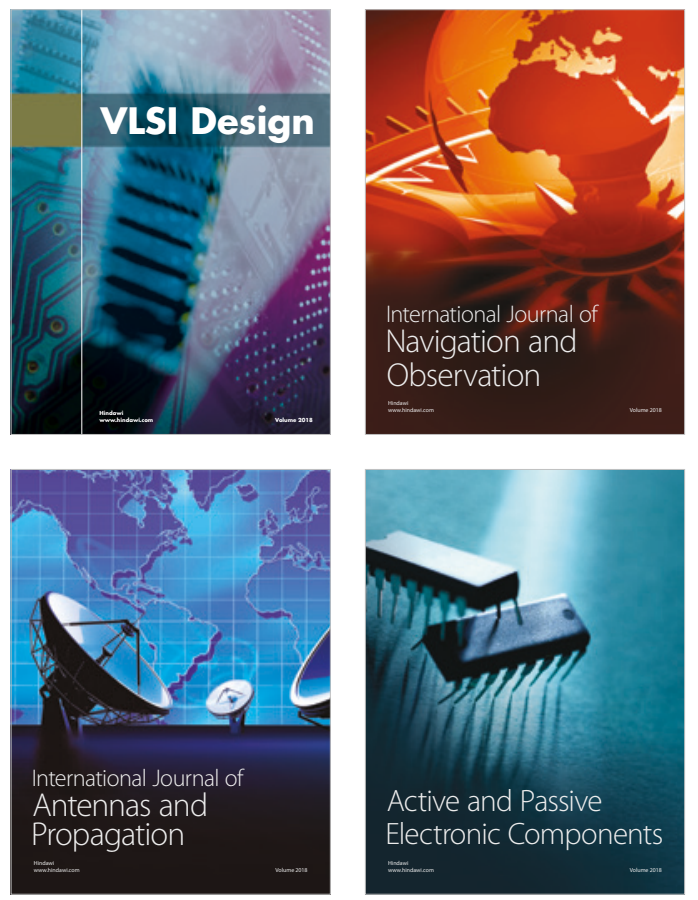
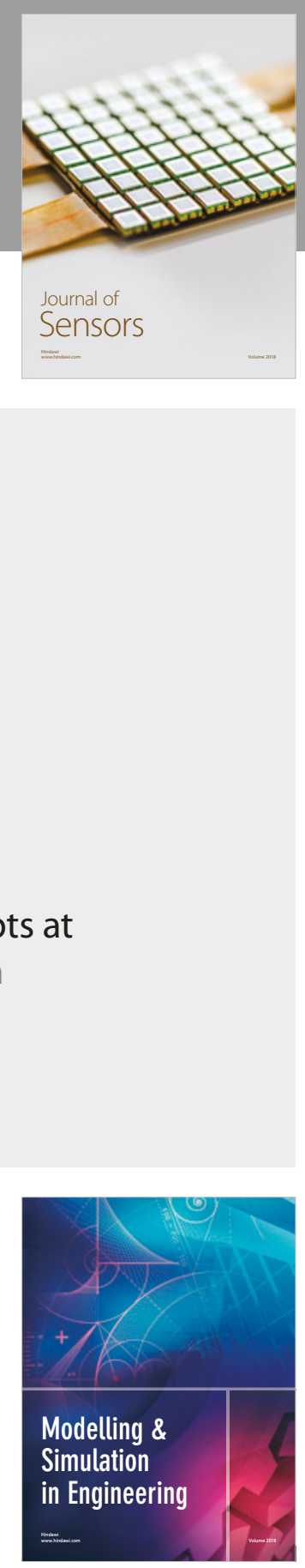

\section{Advances \\ Multimedia}
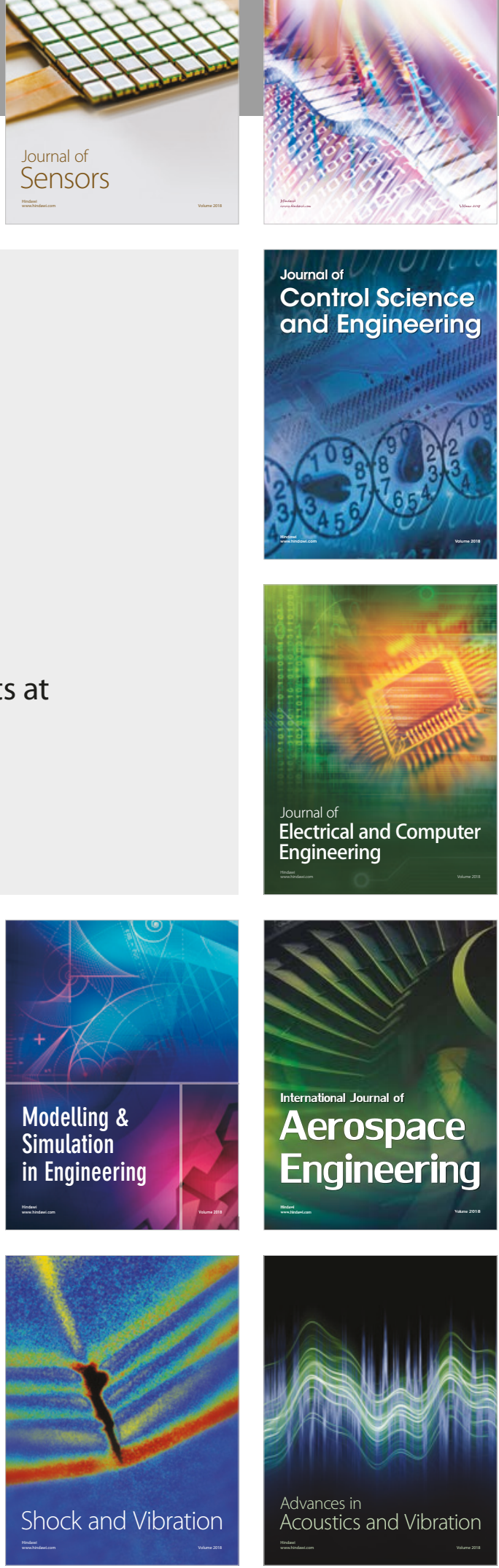